\title{
KNOWLEDGE-INTENSIVE BUSINESS SERVICES AND THE VALUE OF EXPERT INFORMATION
}

\author{
JACEK BEDNARZ \\ John Paul II Catholic University of Lublin, Faculty of Social Sciences, POLAND \\ e-mail: bednarz@kul.pl
}

\begin{abstract}
\begin{tabular}{l|l} 
RECEIVED & 10 December 2018
\end{tabular}
\begin{tabular}{l|l} 
ACCEPTED & 28 December 2018
\end{tabular}

JEL

CLASSIFICATION

E71, L84, O31

KEYWORDS business services; economic value; expert knowledge; product-service system

ABSTRACT This article shows a brief perspective on the timeline between knowledge and innovation management and what is now known as Knowledge Intensive Business Services, where knowledge management has a leading role in the establishment of a competitive advantage in business organizations, a strategy that will allow them to reflect their competitiveness in a changing environment by mastering their innovation competence. This implies that knowledge management has both an inherent part of organizations of the post-industrial era and a strong need to respond to the challenges brought by today's society. Such a relatively new way of doing business dictates significant changes to be made in businesses, starting with their human capital as the key element and asset.
\end{abstract}

\section{Introduction}

Services constitute a crucial form of value creation in many countries. In Europe, the service sector was estimated to be $70.9 \%$ of the GDP in 2017 (The World Factbook, 2018). Among a wide variety of service industries, knowledge-intensive business services (KIBS) are growing rapidly in advanced economies. KIBS, which mainly produce services that are used as intermediate inputs by businesses, are characterized by highly skilled employees 
and a high intensity of knowledge. Advanced products and technologies are increasingly made available as services. Digital transformation amplifies the trend of changing business models, towards offering and selling the utility of a product or a service. Enabled through digital technologies, almost everything becomes a service and traditional manufacturing sees advances in services (Kozłowska, 2017, p. 70). Service industries themselves are also transforming into high tech ventures. Retail, news, the media, mobility, and - certainly - finance and insurance, have become hotbeds of digital services that thrive on advances in information technology. Advanced economies are thus characterized by a strong prevalence of complex service systems.

Generally, it is assumed that in the current state of affairs of the economy, only innovative organizations will survive. It is therefore universally accepted that innovation is the key to ensure the future growth and survival of any business. Innovation allows organizations to coordinate themselves with the changes in the environment, market, consumer demand, and shareholder expectations. The innovation process and decision usually have been focused on the choice between internal or external sources of innovation. The increasing complexity and rapid development of the innovation process in the industry and service sector alike from both economic and management perspectives requires a step beyond this simple dichotomy. Surviving means for many organizations not only creating knowledge in order to enhance their product or service - in a highly competitive market there are organizations that create new knowledge, the same ones that disseminate it and, therefore, the same ones that quickly permeate new processes, products and services are also the same ones that recognize information and knowledge as indispensable resources to expand their competitiveness and increase the quality of their expertise to customers, influencing and integrating their markets. With the appearance of the knowledge-intensive business service, a new business model has emerged with the very rationale of how an organization shall create, capture and deliver value to its customers (Stickdorn, Schneider, 2012, pp. 95-96).

The purpose of this paper is to draw a perspective about the creation, use, and value of expert information within the business model of knowledge-intensive business service. Section 1 focuses on the interdependence between knowledge management and innovation competence in business organizations. Section 2 analyses key aspects of value creation process by knowledge-intensive business unit as an external provider of knowledge and innovation service. Section 3 presents some economic based insights of determining the value of external expert information and its use for innovation management process.

\section{Knowledge Management and Innovation Competence}

From the social point of view, knowledge management focuses on learning as a proper way of its creation in organizations, making them more flexible and thus more efficient. However, from the economic point of view, management of knowledge is identified with the management of intellectual assets such as the protection and commercialization of innovations and intellectual property, in order to use technology to achieve competitive advantages.

The main objective of an information and knowledge-acquiring strategy is to guide every profit-oriented business organization in developing new product and services for competitive advantage. However, there are many factors influencing the product and technology decisions of a firm. Product development and technology sourcing are both complementary streams in studies published at the beginning of the recent industrial development (Henard, Szymanski, 2001, p. 372). While the product development studies focus more on product development and its managerial process, the latter ones dealing with technology sourcing also view product and process innovation 
as the outcome of a business decision. Both are often seen as dichotomous variables (Kotabe, Mudambi, 2009, p. 122). A likely explanation for this dichotomy is that product development, associated with the firm marketing activities, has, in most cases very little to do with the manufacturing process and its technology. Since marketing is traditionally involved in the development rather than the manufacturing of products, both activities of every business organization exist simultaneously.

The process technology-sourcing decision has an additional aspect of the value of analyzing and creating for both, the customer and the firm at the same time. Since the firm faces a highly market-oriented imperative to acquire and incorporate the best possible manufacturing technology, it is the firm objective to manage this in a (cost) efficient way. Rapid changes in technology available to the firm result in a greater concern for possible use of external expert information and its acquisitions. The use of expert information seems to be advisable and in a certain way mandatory, since firms can find it difficult to maintain research efforts along all technological fronts and fields at the same time (Voss, 1994, p. 462). Increasingly important for the firms is, therefore, to focus on the internal development of innovation competence. This happens when implementing within the firm a value-based information and knowledge management system (Tabaszewska, 2002, p. 163). This is how companies have begun to identify and understand that people represent a key factor for their competitiveness since knowledge arises from the human being (Cerchione, Esposito, Spadaro, 2015, pp. 10211-10212). It is through their actions that it is transformed, developed, disseminated and, ultimately, it is applied productively in order to improve the performance and results of the organization. Building the business innovation competence is based on improvement on a personal and organizational level. There is a strong interdependence between personal development and business process optimization. The source of improvement, in this case, is to establish links between and among several single steps and measures of personal development. Subsequently, a chain of well balanced and optimized business operations can be drawn and set up as a business (product developing and manufacturing) procedure. On the organizational level, the main task is to train the learning organization towards the ability to manage its acquired knowledge since knowledge management is associated with the ability to respond to incentives from both internal and external spheres of the firm (Skrzypek, 2000, p. 84). In other words, knowledge management refers to the management of intangible assets that generate value for the organization and, for the most part, has to do with processes related to the acquisition, structuring, and transmission of knowledge. The business innovation competence enables the firm to acquire various information and to process it into knowledge. This seems to be the very core competence of a business organization.

Based on the explanation given by H. Willke (2001, pp. 82-85) a model of production and diffusion of expert information has been formulated (Figure 1). Within this model, core competencies represent the ability to manage the firm activities in all business fields (i.e. sales, marketing, manufacturing, organization, human recourses, logistics, financial management, etc.), since the acquired expert information can be applied in all fields. Both perspectives in this top-down approach, namely experimenting for the future and problem-solving at the present time, are equally important as far as the information diffusion is concerned. However, the most important direction is shown from left to the right on Figure 1. Without proper implementing and integrating of the acquired information and knowledge problem solving and experimenting would never become possible. Every kind of core capabilities rigidity influences the firm's risk exposure. 


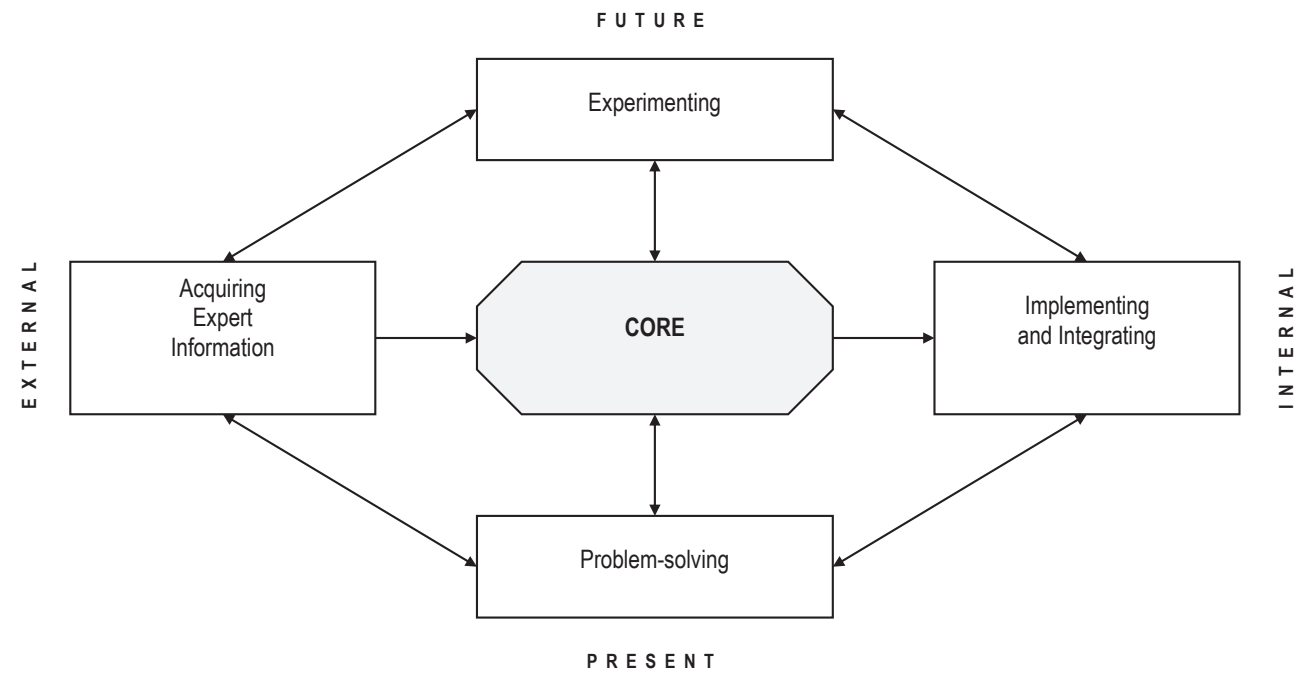

Figure 1. Components of Production and Diffusion of Expert Information

Source: own elaboration based on Willke (2001).

\section{Knowledge-intensive business services and the process of value creation}

The development of knowledge-intensive business services in recent decades can be interpreted as one of the indicators of a successful transformation from an industrial into a knowledge-based economy. The visible results of this process s are innovations in products, services or processes. Nowadays, enterprises can hire almost any conceivable business activity and asset class as a service (Wirtz, Tuzovic, Ehret, 2015, p. 568). Among many possible service providers, a special part is taken by the knowledge-intensive business. Knowledge is both their main input and output and their underlying business activities consist of the accumulation, creation, and dissemination of knowledge for the purpose of developing contextualized and innovative solutions. Gaining an estimate of an approximate share of external business services interested in providing innovative solutions, based on statistical data is still far from being standardized. In several studies (Baláž, 2004; Koch, Strotmann, 2006; Borodako, Berbeka, Rudnicki, 2015) different classifications were employed. In any event, a contract with the service provider must have been a viable strategy for the contracting partner.

KIBS are primarily characterized by their abilities to collect information and knowledge externally and to transform these in combination with internal knowledge into service outputs. Those outputs are in most cases customized to particular user's requirements. Consequently, close customer relations often play a decisive role in the provision of these services (Tether, Hipp, 2002, pp. 164-165). This interaction can be so close that the service cannot be provided without both the service user and provider taking part in its daily operations. This is also the main feature of the innovative characteristics in the business model of KIBS. Against this background, it becomes particularly urgent to enquire whether the primary role of the knowledge provider (i.e. KIBS) is actually the knowledge production. Furthermore, it should be focused even more closely what particular kind of knowledge the KIBS use and what role they perform in the economy. 
I. Nonaka and H. Takeuchi (1995, pp. viii-ix) draw on the distinction between the objective and subjective knowledge. The objective knowledge basically represents the explicit knowledge ("knowing about"), while the subjective knowledge essentially stands for the "know-how" or tacit knowledge. The explicit knowledge is believed to be easy to define, transfer and store (scientific publications). In contrast, the tacit knowledge, made of experience or ideas, is to a high extend personal and cannot be easily (if at all?) codified or converted. Equally important is also a clear delimitation between individual and organizational knowledge. The latter consists of both knowledge of individuals and the routines, procedures, etc., which are developed at an organizational level and shared by its members. Thus the process of knowledge transfer and generation is associated with the interaction of organizational and individual knowledge.

It is useful to distinguish further between different types of knowledge. B.T. Asheim and L. Coenen (2005, pp. 1175) distinguished between analytical and synthetic knowledge. Analytical knowledge mainly refers to (scientific) knowledge to understand and explain empirical phenomena (know-why). This knowledge is highly codified, thus reliable and verifiable. In this context, the tacit knowledge remains a necessary complement to understand and validate analytical knowledge. Synthetic knowledge, in turn, refers to a practical know-how and is more tacit and problem-driven. Typically, synthetic knowledge is used to solve a practical problem. This is the very argument, what kind of knowledge customers of the many KIBS shall be provided with. Both KBIS and their clients are keen to ensure that the problem-solving solution results from the synthetic knowledge. B.T. Asheim (2007, p. 225) and B.T. Asheim, L. Coenen and J. Vang (2007, pp. 660-661) later added symbolic knowledge to the knowledgebase classification as a third type of knowledge, used foremost in a social context to produce social and cultural meaning via the media and advertising industries. All three types of knowledge are used and produced in every sector of the economy. However, we can argue that the key type of knowledge underlying innovation processes, as represented by the KIBS, differs substantially between industries. Analytical knowledge is key to the innovation process in science-based sectors, such as the pharmaceutical, biotechnology and nanotechnology industries. By contrast, synthetic knowledge is dominant (Davids, Frenken, 2018, p. 32) in artifact engineering for the vehicle, electronics and construction industries. Symbolic knowledge should be associated with the knowledge of cultural codes underlying cultural industries and advertising.

KIBS perform important functions in the economic system. Firstly, they diffuse knowledge in the form of specific and synthetic expert knowledge. As a result of the increase in the amount of information and knowledge KIBS are closely linked, not only to knowledge diffusion but more generally to the modernization and rationalization process of the economy. Secondly, they integrate different stocks of knowledge and competencies. The combination of knowledge of various functional areas may be of importance during the innovation process. The ability of the KIBS to integrate different types of specialized knowledge explains unequivocally why both informal and formal networks and cooperation play an important role in KIBS business performance. Thirdly, they produce new, foremost synthetic knowledge. During the development of their assigned activity, KIBS collect, transform and create new knowledge, most of the tacit type.

KIBS maintain also long-term relationships with their clients which allow them to acquire both tacit and explicit knowledge about their client firms. This knowledge is used to adapt solutions for innovating problems to the specific structure and culture of client firms. During the process of new knowledge creation existing knowledge is used to develop a solution to a specific problem. This knowledge is available through the expertise of the project team (academics as well as non-academics) or from the results of earlier projects - part of the body of scientific 
knowledge. Available knowledge, as well as newly generated context-specific knowledge, is applied in order to solve a specific problem. A spin-off product resulting from the accepted original problem-solving solution is the additional generic knowledge perceived as emerging experience. Generic knowledge is the knowledge that is generally applicable to answer similar kinds of problems the organization is dealing with. As science is interested in the nature and behaviour of observable phenomena it seeks knowledge that has relevance and validity beyond a specific context of the actual assignment. Through reflective processes, single expert and expert teams can use the specific knowledge developed in the project for the further development of existing methods and theory (research). Conclusions of general relevance can be drawn and in this sense, generic knowledge will eventually be developed. The generic knowledge increases the body of knowledge in scientific communities and the knowledge applicable to societal problems.

\section{Determining the Economic Value of Expert Information}

A very important economic aspect of contracting and using expert information in the innovation management process is to determine its economic value and cost. The main product of knowledge-intensive service contractor is the expert information and then the value of this product will be of importance for contracting partys. The expert information - almost as a quantum of actual knowledge - bears a solution to the problem addressed and its utility shall not be put in question. Since using external information is an activity of discretionary nature to the contracting firm, it is relatively easy for a manager to make an impact on costs by cutting discretionary expenses related to innovation. The practice of reducing expenditures on research and development, training, advertising (among many others) will have a real effect in the short term. Factors, such as opportunism and bounded rationality, may influence the decision-making process to acquire and process expert information (Williamson, 1985, pp. 30-31). Since costs could be lowered, profits are boosted. There will be, however, other effects in the long term. Contrasting adverse effects will arise on overall business performance as sales drop off due to product or service deterioration, or lack of new products. Wrongly balanced interdependence between the value and cost of expert information can undermine the competitiveness of a given business. Subsequently, the long-term well-being of the firm can be threatened.

Here the question arises: How to determine the value of expert information? One possible solution to this question emerges from well-established accounting methods (i.e. activity-based costing). Methods of this kind have been successfully integrated into today's business management curriculum. The purpose of those methods is to answer the question whether or not a cost based on a single or complex activity does add value to the business process (Tanaka, Yoshikawa, Innes, Mitchell, 1994, p. 172).

Another possible explanation of the expert information value arises when accounting for expected value in case, which means the expert has the information required. Possessing information required by a business firm is like sending a signal. The willingness to pay for the information is a reaction to the incentive received from the expert. As a result, a contract between those parties is signed The economic rationale behind those stylised facts is that the business expects an improvement, i.e. a positive net effect of using the acquired information, after all costs (including expert's salary) are taken into account. The positive net effect is responsible then for the firm economics of scale (Kalirajan, 1997, pp. 255-256). The acquired information represents itself a measurable value. It is the difference between the expected value of the net effect of using valuable information and the value of the net effect when no valuable information was used. 


\section{Conclusions}

This article shows a brief perspective on the timeline between knowledge and innovation management and what is now known as Knowledge Intensive Business Services, where contextualized knowledge production has a leading role in the establishment of a competitive advantage in business organizations.

A relation of reflexivity can be found at the core of knowledge production and perception. Producing services, based on synthetic knowledge, seems to be a straightforward approach. The main task is to organize a solution to a problem (in form of an operation or a treatment). It is to place a bundle of capabilities and competencies at the disposal of a client and to elaborate a solution (Gadrey, Gallouj, Weinstein, 1995, pp. 14-15). For KIBS elaborating a solution means conducting a scientifically oriented study with the purpose of the contract, i.e. creation of knowledge artifacts (procedures, treatment) as they are developed and used by people with the goal of solving problems (Hevner, March, Park, Ram, 2004, p. 82). A spin-off product resulting from the accepted original problemsolving artifacts is the additional generic knowledge perceived as emerging experience. The experience and the knowledge stored in the knowledge-intensive business organization memory are not purely historical in their nature. Their purpose can turn to be or become also predictive because the organization experience is not only its memory (Kransdorff, 1998, p. 177). The organizational experience cannot only provide the records and evidence for the business organization, its members or partners in the past, but also function as a dependent frame of reference and an empirical mode for the decision to come (Paoli, Prencipe, 2003, pp. 158-159) and for the collective action. In addition, knowledge-intensive working includes an obvious, though contractual, relation to an experience of a lack, which evolves from the cognitive gap of the addressed, but still unsolved problem.

\section{Referencess}

Asheim, B.T. (2007). Differentiated knowledge bases and varieties of regional innovation systems. Innovation: European Journal of Social Science Research, 20 (3), 223-241.

Asheim, B.T., Coenen, L. (2005). Knowledge bases and regional innovation systems: Comparing Nordic clusters. Research Policy, 34 (8), 1173-1190.

Asheim, B.T., Coenen, L., Vang, J. (2007). Face-to-face, buzz and knowledge bases: Socio-spatial implications for learning, innovation and innovation policy. Environment and Planning C: Government and Policy, 25 (5), 655-670.

Baláž, V. (2004), Knowledge-intensive business services in transition economies. The Service Industries Journal, 24 (4), 83-100.

Borodako, K., Berbeka, J., Rudnicki, M. (2015) Tourism Enterprises as Buyers of Knowledge-Intensive Business Services. SAGE Open, $5(1), 1-10$.

Cerchione, R., Esposito, E., Spadaro, M. (2015). The spread of knowledge management in SMEs: A scenario in evolution. Sustainability, 7 (8), 10210-10232.

Davids, M., Frenken, K. (2018) Proximity, knowledge base and the innovation process: towards an integrated framework, Regional Studies, 52 (1), 23-34.

Gadrey, J., Gallouj, F., Weinstein, O. (1995). New modes of innovation. How services benefit industry. International Journal of Service Industry Management, 6 (3), 4-16.

Henard, D., Szymanski, D. (2001). Why some new products are more successful than others. Journal of Marketing Research, 38 , 362-375.

Hevner, A., March, S., Park, J., Ram, S. (2004) Design science in information systems research. Management Information Systems Quarterly, 28 (1), 75-105.

Kalirajan, K. (1997). A measure of economic efficiency using returns to scale. Economic Letters, 56, 253-257.

Koch, A., Strotmann, H. (2008). Absorptive capacity and innovation in the knowledge-intensive business service sector. Economics of Innovation and New Technology, 17 (6), 511-531. 
Kotabe, M., Mudambi, R. (2009). Global sourcing and value creation: Opportunities and Challenges. Journal of International Management, 15 (2), 121-125.

Kozłowska, J. (2017). Rozwój koncepcji integracji produktowo-usługowej (product service systems). Modern Management Review, 24 (1), 69-81.

Kransdorff, A. (1998). Corporate Amnesia: Keeping Know-How in the Company. Oxford: Butterworth-Heinemann.

Nonaka, I., Takeuchi, H. (1995). The knowledge creating company: How Japanese companies create the dynamics of innovation. Oxford: Oxford University Press.

Paoli, M., Prencipe, A. (2003). Memory of the organization and memories within the organization. Journal of Management and Governance, 7 (2), 145-162.

Skrzypek, E. (2000). Jakość i efektywność. Lublin: Wydawnictwo UMCS.

Stickdorn, M., Schneider, J. (2012). This is service design thinking: basics, tools, cases. Amsterdam: BIS-Publishers.

Tabaszewska, E. (2002). Rola zarządzania informacją w integracji działań przedsiębiorstwa. Prace Naukowe Akademii Ekonomicznej we Wrocławiu, 928, 162-167.

Tanaka, M., Yoshikawa, T., Innes, J., Mitchell, F. (1994). Contemporary Cost Management. London: Chapman \& Hall.

Tether, B., Hipp, C. (2002). Knowledge intensive, technical and other services: patterns of competitiveness and innovation compared. Technology Analysis \& Strategic Management, 14 (2), 163-182.

The World Factbook (2018). Retrieved from: https://www.cia.gov/library/publications/the-world-factbook/geos/ee.html.

Voss, C. (1994). Significant issues for the future of product innovation. Journal of Product Innovation Management, 11, 460-463.

Williamson, O. (1985). The economic institutions of capitalism. Firms, markets, relational contracting. New York: The Free Press.

Willke, H. (2001). Systemisches Wissensmanagement. Stuttgart: Lucius \& Lucius.

Wirtz, J., Tuzovic, S., Ehret, M. (2015). Global business services: Increasing specialization and integration of the world economy as drivers of economic growth. Journal of Service Management, 26 (4), 565-587.

Cite this anticle aS: Bednarz, J. (2018). Knowledge-intensive business services and the value of expert information. European Journal of Service Management, 4 (28/2), 47-54. DOI: 10.18276/ejsm.2018.28/2-05. 